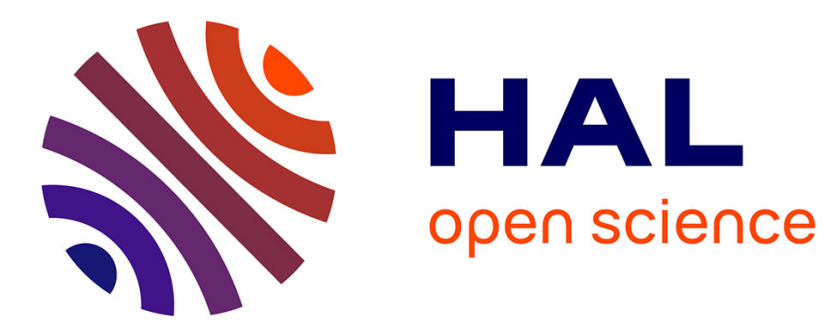

\title{
Education in the Digital Networked World
}

Torsten Brinda, Ira Diethelm

\section{To cite this version:}

Torsten Brinda, Ira Diethelm. Education in the Digital Networked World. 11th IFIP World Conference on Computers in Education (WCCE), Jul 2017, Dublin, Ireland. pp.653-657, 10.1007/978-3-31974310-3_66. hal-01762885

\section{HAL Id: hal-01762885 \\ https://hal.inria.fr/hal-01762885}

Submitted on 10 Apr 2018

HAL is a multi-disciplinary open access archive for the deposit and dissemination of scientific research documents, whether they are published or not. The documents may come from teaching and research institutions in France or abroad, or from public or private research centers.
L'archive ouverte pluridisciplinaire HAL, est destinée au dépôt et à la diffusion de documents scientifiques de niveau recherche, publiés ou non, émanant des établissements d'enseignement et de recherche français ou étrangers, des laboratoires publics ou privés. 


\title{
Education in the Digital Networked World
}

\author{
Torsten Brinda ${ }^{1}$ and Ira Diethelm ${ }^{2}$ \\ ${ }^{1}$ University of Duisburg-Essen, Computing Education Research Group, Germany \\ ${ }^{2}$ University of Oldenburg, Computing Education Research Group, Germany \\ ${ }^{1}$ torsten.brinda@uni-due.de, ${ }^{2}$ ira.diethelm@uni-oldenburg.de
}

\begin{abstract}
The steadily advancing digitalization of our world requires that educational systems adequately prepare everybody for the resulting challenges. Different actors in educational systems often see the solution either in digital media education, or computing education. This position paper presents a combined model the so-called "Dagstuhl triangle", which was developed in collaboration of about 30 computer scientists, computing and media education researchers, teachers, and representatives from IT companies and foundations.
\end{abstract}

Keywords: Computing Education, Media Education, Digital Education, K12.

\section{Introduction}

Digital change, which affects our entire society, culture and economy, is shaped by people who are qualified in computer science, persons who have either completed vocational training or a university degree in computer science or who have acquired such competencies by themselves. These people develop new devices and device categories, associated operating systems, as well as applications and apps for a variety of purposes, not just personal needs. By providing AppStores developers of large operating systems (such as Windows, macOS, iOS, Android, Linux) have created infrastructures and distribution channels, which in principle enable everyone to implement and make available software solutions to problems of any kind. The ICT economy, which drives the world's change through digitization and thus plays a key role in shaping social and work-related processes, has been "complaining" internationally about a shortage of skilled workers - according to forecasts, this deficit could lead to e.g. 120,000 missing academics by the year 2030 in Germany alone $^{1}$.

The developments of the past years have shown that the progress of digitalization and automation is by no means a short-term phenomenon, rather steadily advancing and that new device categories, applications and application scenarios are constantly being developed. Although the term "digitization" dominates the description and discussion of phenomena and artefacts, corresponding innovations have also been described as "new media", "modern information and communication technologies" or more broadly, as computing systems before. An end to these innovations and technological developments is not in sight. The concrete systems (applications and

http://www.it-business.de/fachkraeftemangel-spitzt-sich-zu-a-541910/ 
devices) are subject to a constant change (in particular by new versions with modified user interfaces) and disappearing off sight, while the underlying technical concepts of computer science are time-stable. Many of the above-mentioned systems and applications can, in principle, be used as teaching media for certain technical contexts, but not all. However, all of these systems are based on certain basic principles of computer science, which include, but are not limited to, terms such as encoding and modelling of information, algorithms, data structures, programming and network communication.

\section{Educational Perspectives on the Digital Networked World}

Advancements in digitalization make young people get in contact with a wide range of computing systems. As a result, they develop mental models of their structure and working principles. These self-constructed models do not always correspond to the scientific ones: they often are incomplete, partly correct, faulty. So far, only a few empirical findings on the everyday conceptions of pupils in the field of computer science (e. g. [2, 3]) are available. However, understanding the world and co-shaping it requires correct models, which must be developed in school by teachers with appropriate professional competence. But what is needed to really understand the "digital world"? How can this be characterized without a long list of normative settings of content or competencies?

In the so-called Dagstuhl declaration on "Education in the Digital Networked World" [1] (in short: "digital education”) it was argued that in comprehensively oriented education the phenomena, artefacts, systems and situations of the "digital world" encountered and perceived by students must be regarded from three different perspectives: the structural perspective, the social-cultural perspective and the application-oriented perspective, see fig. 1. This means: from an application-oriented perspective, the question should be answered how and when specific systems and tools are used for which purposes, in a socio-cultural perspective the effects and interactions between system, individual and society are examined and the consideration of systems "from within" from a structural perspective provides insight into how special and typical systems (in principle) are internally structured and how they function. All are needed to provide sustainable education as a solid ground for a “digital society".

The approach values existing views such as user training, media education and computing education and has the intention of integrating these views into a coherent overall concept. In order to comprehensively understand all the above-mentioned facets and thus to contribute to the construction of a coherent image of the learners with regard to the "digital world", a corresponding intake of all the mentioned perspectives is necessary. Interestingly, already in 1983 an IFIP working group for elementary education stated that "the aim of elementary education is to help every child reach his/her full human potential and to achieve social, emotional, and mental maturity. When computers are introduced into schools, we should be concerned about three levels of use - the technical level (how and when to use them), the understanding level (why they bring about the results they do) and the reflective level (the personal and societal values involved in using them)." [4] In order to enable 
learners for active participation in and shaping of the "digital world" with others, these perspectives should again be taken up from a creating point of view as well. From an application-oriented perspective, it is then possible to question how tasks or problems of everyday life can be performed resp. solved using existing systems. From a socio-cultural perspective, it is considered how interactions between systems, individuals and society can be shaped, and finally, from a structural point of view, it is investigated how systems for the solution of problems can be developed, that is, systematically planned and subsequently programmed. The Dagstuhl triangle (see fig. 1) provides an overall model for digital education, i.e. learning about the "digital world". It explicitly includes the use of computer systems as teaching tools in all disciplines, but goes far beyond that by including computing competences, which make active participation also from a technical point of view possible.

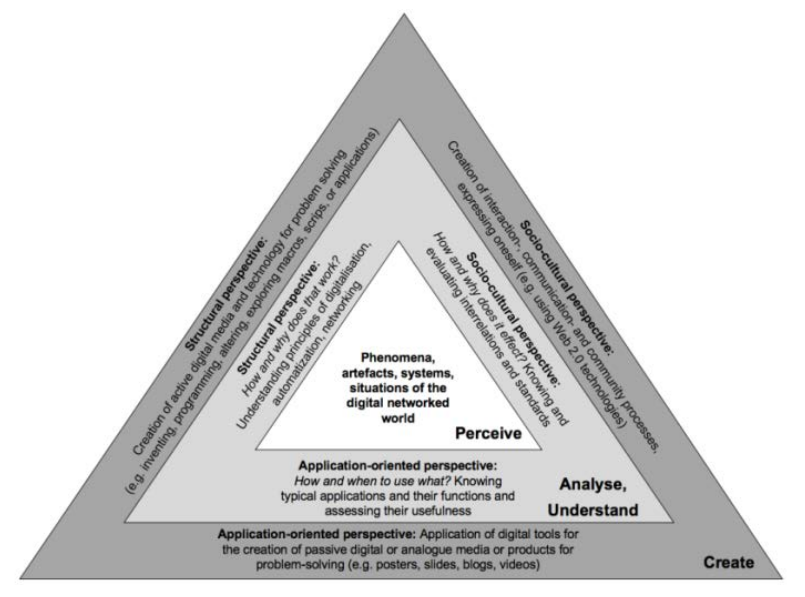

Fig. 2. Educational Perspectives on the Digital Networked World ("Dagstuhl perspectives”)

Public discussions on the value and the incorporation of computing competences into education show that various actors have a wide-ranging understanding of the terminology, which differs considerably from scientific definitions (e.g. [5]). For example, the term "informatics" is also used by some actors for the use of digital media in educational processes, as well as for user qualification regarding standard software, others associate aspects of computer administration or programming with this term. Even if computer-based systems are involved, computer science is a scientific discipline. Some actors also occasionally demand that "algorithms" or "data structures" should be integrated into school and use these terms as representatives of the discipline [6]. Even though these concepts are of great importance within the discipline, they are however hardly learnable in an isolated way that would lead to systematic development of an individuals' computing competences. A similar approach would be in mathematics to deal with just the function or - or even only with the set concept. Both concepts are disciplinarily central, but there are other important concepts, such as the concept of probability, which in turn refers to the concepts function and set. 
Computer science is the science of the systematic processing of information, in particular the automatic processing with the help of computers. It deals with the principles and procedures underlying the understanding and modelling of automatic information processing including modelling and distributing via networks and its application in the development of computing systems [7] and is an academic discipline [8, p. 3]. In the Anglo-American language area, the underlying cognitive processes are referred to as "Computational Thinking" [9], a way of thinking that goes beyond hardware and software and provides a framework to analyse systems and problems.

In this context, the question is sometimes raised as to why knowledge about computer science is necessary, if the aim is "only" the competent use of computer systems and no corresponding professional career in the field of computer science is pursued. This question could be applied in the same way to all other school subjects, for example: Why must one be able to interpret poems, if one does not want to become a poet? Why do you have to learn mental arithmetic, if you can use a pocket calculator later? Why do you have to analyse the physique of animals in detail, if you do not want to become a veterinarian? etc. Through the discipline-specific ways of creating a separate approach to the respective discipline results. All the above questions can therefore be answered, for example, with reference to overall educational goals, such as "participation" and resp. or "world understanding”.

\section{Conclusions}

The teaching of computing competences and digital media education are, therefore, essentially complementary fields that can substantially benefit from each other in the sense of the above model. While computer science is concerned with teaching the underlying principles of the "digital world" and enabling learners to actively participate in the "digital world", the goal of media education is to make learners competent and reflected users of existing IT systems [8, p4]. Both aspects are important and central to education in the "digital world". Even if advertisements propagate that there is "an app for everything”, we have to prepare young people for a world that does not yet exist, involving technologies that have not yet been invented, and that present technical and ethical challenges of which we are not yet aware [8, p. 3]. Comprehensive education must therefore also look at digitalization from a computing perspective as a subject of instruction. Various national approaches have already been developed and implemented [10]. Overall concepts of education in the digital age should therefore integrate all the above-mentioned perspectives and come to the conclusion that not either digital literacy or computing education is the solution for the needs of the digital age - it is the adequate combination of both, as summarized in the Dagstuhl declaration [1]:

1. Education in the digital networked world must be taken into consideration from a structural, socio-cultural and application-oriented perspective.

2. A separate learning area (e.g. a mandatory school subject) must be set up in schools, in which the basic concepts and competences for the orientation in the digital networked world are acquired.

3. In addition, it is task of all subjects to integrate and implement digital literacy. 
4. Digital education in the above-mentioned learning area as well as within the other subjects must be carried out continuously across all school levels for all pupils following a spiral curriculum.

5. An accordingly well-founded teacher training in the related sciences of computer science and media education is essential for this. This means:

a. A study component within teacher education, which includes concepts and competencies from the fields of computer science and media education, has to be established.

b. All related sciences must meet the challenge and conduct further research and develop concepts for digital education.

c. Comprehensive training and further education for teachers from the above-mentioned perspectives must be set up in the short term.

\section{References}

1. Brinda, T., Diethelm, I., Gemulla, R., Romeike, R., Schöning, J., Schulte, C.; et al.: Bildung in der digitalen vernetzten Welt - Dagstuhl Erklärung (in German), URL: https://www.gi.de/ aktuelles/meldungen/detailansicht/article/dagstuhl-erklaerung-bildungin-der-digitalen-vernetzten-welt.html (2016).

2. Diethelm, I., Wilken, H., Zumbrägel, S.: An investigation of secondary school students' conceptions on how the internet works. Proceedings of the 12th Koli Calling International Conference on Computing Education Research. ACM, New York, 67-73 (2012).

3. Rücker, M.T., Pinkwart, N.: Review and Discussion of Children's Conceptions of Computers. Journal of Science Education and Technology 25(2), 274-283 (2016).

4. Tinsley, J.D., Tagg, E.D. (eds.): Informatics in elementary education. Proceedings of the IFIP WG 3.1 Working Conference on Informatics in Elementary Education. Elsevier, Amsterdam (1984).

5. Institut für Bildung in der Informationsgesellschaft gGmbH: Stakeholder-Studie zum Bundestagsbeschluss. Durch Stärkung der Digitalen Bildung Medienkompetenz fördern und digitale Spaltung überwinden (in German). http://www.ibi.tu-berlin.de/images/ 161013_IBIStudie_Digitale_Bildung_BT-Beschluss_Langfassung.pdf (2016).

6. Secretary of the Standing Conference of the Ministers of Education and Cultural Affairs of the Federal Countries of Germany: Bildung in der digitalen Welt. Strategie der Kultusministerkonferenz (in German).

https://www.kmk.org/fileadmin/Dateien/pdf/PresseUndAktuelles/2016/Bildung_digitale_ Welt_Webversion.pdf (2016).

7. German Informatics Association (ed.): Was ist Informatik? (in German). Position paper, URL: https://www.gi.de/themen/was-ist-informatik.html (2005).

8. Computing at School Working Group: Computer Science - A curriculum for schools. https://www.computingatschool.org.uk/data/uploads/ComputingCurric.pdf (2012).

9. Wing, J.M.: Computational thinking. Communications of the ACM 49(3), 33-35 (2006).

10. Hubwieser, P., Giannakos, M.N., Berges, M., Brinda, T., Diethelm, I., Magenheim, J., Pal, Y., Jackova, J., Jasute, E.: A Global Snapshot of Computer Science Education in K-12 Schools. Proceedings of the 2015 ITiCSE on Working Group Reports (ITICSE-WGR '15). ACM, New York, 65-83, http://dx.doi.org/10.1145/2858796.2858799 (2015). 